\title{
Association between Cigarette Package Warning Messages, Self-Efficacy, and Smoking Behavior among Students at Health Polytechnic in Surakarta, Indonesia
}

\author{
Roy RomeyDaulas Mangunsong1), Bhisma Murti²), Mahendra Wijaya3) \\ 1)Department of Speech and Occupational Therapy, Health Polytechnic Surakarta \\ 2)Masters Program in Public Health, Universitas Sebelas Maret \\ 3)Faculty of Politics and Social Sciences, Universitas Sebelas Maret
}

\begin{abstract}
Background: Total number of smokers around the worldwide is approximately 140 million. The number ofdeaths causedby tobacco smoking related diseases is approximately 300,000 per year. Average age to start smoking is $\mathbf{1 7 . 6}$ years. The high number of smokers at young age indicates that public awareness of the dangers of smoking is still very low. This study aimed to determine theassociation between cigarette package warning messages, self-efficacy, and smoking behavior among students.

Subject and Methods: This was an analytical observational study with cross sectional design, carried out in Surakarta, Indonesia. A total of 71 students were selected by random sampling. The dependent variable was smoking behavior. The independent variables were illustrated the dangers of cigarette smoking advertising and self-efficacy. The data were collected by questionnaire and analyzed by regression logistic.

Results: There was a relationship between ads illustrated the dangers of cigarette smoking with smoking behavior $(\mathrm{OR}=2.87 ; 95 \% \mathrm{CI}=0.91$ to $9.03 ; \mathrm{p}=0.071)$. There was a relationship between the smoking behavior of yourself with the efficacy $(\mathrm{OR}=0.23 ; 95 \% \mathrm{CI}=0.07$ to $0.74 ; \mathrm{p}=0.013)$. The ads illustrated the dangers of cigarette smoking and self-efficacy was able to explain the smoking behavior of $16.2 \%$.

Conclusion: There is a relationship between the ads illustrated the dangers of cigarette smoking, self-efficacy, and the smoking behavior.
\end{abstract}

Keywords: cigarette package warning messages, self-efficacy, smoking behavior

\section{Correspondence:}

Roy Romey Daulas Mangunsong. Department of Speech and Occupational Therapy, Health Polytechnic Surakarta. Email: Surakartaroypoltekstw@gmail.com

\section{BACKGROUND}

Indonesia is one of the developing countries that has high levels of cigarette consumption and cigarette production. Research shows that Indonesia is currently ranked fourth in the world as a nation whose population is most fond of smoking. About 140 million people consume tobacco every day. Every year, cigarette consumption reaches 199 billion cigarettes (Kholish, 2011). As a result of the consumption of cigarettes, the number of deaths from diseases from smoking habits reached 300 thousand per year. Nearly $60 \%$ of deaths in Indonesia are caused by non-communicable diseases (PTM) caused by cigarettes (Nuradita and Maryam, 2013). The average age of starting to smoke nationally is $\mathbf{1 7 . 6}$ years with the highest percentage of people who start smoking every day at the age of 15-19 years, most in school children and tend to increase with increasing economic status (Maseda et al., 2013).

The high number of smokers at a young age shows that public awareness of the dangers of smoking is still very low. 
This is very unfortunate, along with the incessant anti-smoking campaign, because smoking is a risk factor for the incidence of cardiovascular disease, cancer, stroke, bronchitis, asthma, pneumonia and other respiratory diseases (BP POM, 2005). Smoking can cause cancer and fetal disorders in pregnant women (Foulds et al., 2003), diabetes, obesity, impotence, respiratory disorders, abnormalities in the heart and lungs inflammation of the stomach wall and stroke (Berry and Howe, 2005).

The Indonesian Government issues Government Regulation No. 19 of 2003 which requires every cigarette manufacturer to include a warning label on the dangers of smoking on every cigarette package. The existence of these regulations aims to give a warning about the dangers of cigarettes consumed by every cigarette consumer in the hope that by knowing the dangers of smoking, cigarette consumers have the intention to stop smoking. But the warnings on cigarette packs in Indonesia only fulfill less than 20\% of cigarette packs. This is very far from what is required by the Framework Convention on Tobacco Control (FCTC), which includes pictorial warning labels of 50\% of cigarette packs (Prabandari et al., 2009).

Based on this, the Government of Indonesia issued a new policy in the form of Government Regulation No. 109 of 2012 and also the Minister of Health Regulation No. 28 of 2013 that all cigarette companies must include warnings about the dangers of smoking in the form of pictures and writing on tobacco product packaging or that all cigarette products in the country must include a warning about the dangers of smoking to health with a scary image on cigarettes where the government tries to suppress the number of smokers by requiring warnings about the dangers of smoking to health with creepy images on cigarette packs.

The existence of government regulations stating the dangers of smoking in the hope that people can stop smoking is not an easy matter, because cigarettes contain nicotine which can cause addictive properties, which can make smokers become addictive. Besides, environmental and cultural factors also make cigarettes very difficult stopped.

Various types of techniques have been carried out to reduce cigarette consumption, such as by labeling the cigarette packs, but it will not work to stop smokers if without the belief from inside to stop smoking. According to Ogden (2007), behavior can be generated through expectations, incentives, and social cognition, where in these expectations include selfefficacy in them, namely the hope that individuals are able to carry out the desired behavior. So in shaping smoking cessation behavior, there must be self-confidence from the smoker that he is able to stop himself from smoking. Self-efficacy was found to be associated with successful smoking cessation in adults (T'riet et al., 2008).

The existence of a label accompanied by an image on the warning package on the dangers of smoking is a stimulus that will be addressed for smokers. The information label about the dangers of smoking on the cigarette packaging stated is intended so that individuals can read the information conveyed.

Cigarette consumers who read the writing and see the picture on the label are expected to choose, organize, and interpret information about the product in the label. Kurniadi (2005) states that there are two possible attitudes that will emerge in cigarette consumers, namely cigarette consumers will be positive about the warning 
label of the dangers of smoking on cigarette packaging so that they are aware that the cigarettes they smoke will be harmful or give negative attitude towards the warning label of smoking on cigarette packaging by ignoring the bad effects of cigarettes smoked.

Attitudes are influenced by two aspects, namely the belief of someone about what will happen if they do the expected behavior (behavioral belief) and assessment of whether the results are good or bad (evaluation of behavioral out-comes) (Kumalasari, 2012).

The existence of government regulations stating the dangers of smoking in the hope that people can stop smoking is not an easy matter, because cigarettes contain nicotine which can cause addictive properties, which can make smokers become addictive. Besides, environmental and cultural factors make cigarettes very difficult to stop.

Various types of techniques have been carried out to reduce cigarette consumption, such as by labeling the cigarette packs, but it will not work to stop smokers if without the confidence of inside to stop smoking. According to Ogden (2007), behavior can be generated through hope, incentives, and social cognition, which in the hope includes self-efficacy in it, namely the hope that individuals are able to carry out the desired behavior. So, in shaping smoking cessation behavior there must be self-confidence from the smoker that he is able to stop himself from smoking. Selfefficacy was found to be associated with successful smoking cessation in adults (Triet et al., 2008).

Health Polytechnic Surakarta is one of the universities in the health sector. Those who have knowledge about the dangers of smoking, higher education, and working in the health sector should avoid smoking.
In fact, those who have knowledge about the dangers of smoking, those who are highly educated even some of those who work in the health sector (such as health students, nurses and doctors) do not necessarily reject smoking behavior. Moreover, warnings about the dangers of smoking have been written clearly and big on every pack of cigarettes produced, but in reality smoking behavior is not reduced (Wismanto and Sarwo, 2010).

Students who study in the Faculty of Health are expected to have better health care and behavior than students who study in Non-Health Faculties, because what they learn is closely related to the world of health. The results of the study on Health Faculty students showed that smoking was delicious, some claimed to feel the pleasure of smoking after eating, and some claimed to feel the pleasure of smoking while being alone (Salawati and Amalia, 2010).

Health personnel play a very important role in the control of public health, they are the most likely to deal with smokers and non-smokers in their daily practice, have regular and close contact with patients (Sun et al., 2010). Regulations in the Health Polytechnic Surakarta society is quite strict prohibiting students from smoking in the campus area and during study hours, but this behavior becomes uncontrolled when students are off campus and outside of school hours, special activities on health promotion about the dangers of smoking are very rarely done in campus area.

The purpose of this study is to analyze the relationship of cigarette advertising illustrated the dangers of smoking and selfefficacy with smoking behavior.

\section{SUBJECTS AND METHOD}

The research location was in the Surakarta Health Ministry Polytechnic. The population of this study was male students of 
Surakarta Health Polytechnic 2014/2015 academic year, amounting to 241 students. The sampling technique of this study was simple random sampling with a sample of 71 people. The data collection techniques were using questionnaires. The free variable is cigarette advertising illustrating the dangers of smoking and self-efficacy, the dependent variable is smoking beha- vior. The data analysis was conducted using a multiple logistic regression.

\begin{tabular}{ll}
\hline \multicolumn{4}{c}{ RESULTS } \\
\hline The results of research on cigarette
\end{tabular}
advertising illustrated the dangers of smoking, self-efficacy and smoking behavior can be seen in Table 1 .

Table 1.The description of study variables

\begin{tabular}{lcc}
\hline \multicolumn{1}{c}{ Variable } & Total & \% \\
\hline Cigarette advertisements & & \\
Not exposed & 21 & 29.6 \\
Exposed & 50 & 70.4 \\
Self-Efficacy & & \\
Low & 27 & 38.0 \\
High & 44 & 62.0 \\
Smoking Behavior & & \\
Not smoking & 28 & 39.4 \\
Smoking & 43 & 60.6 \\
\hline
\end{tabular}

The results showed that the majority of study subjects exposed to cigarette advertisements illustrated the danger of smoking for about 50 people (70.4\%). The majority of research subjects have high self- efficacy for about 44 people (62.0\%). Subjects who were smokers were 43 people (60.6\%) and those who did not smokewere 28 people (38.0\%)).

Table2. The relationship of cigarette advertising illustrates the dangers of smoking with smoking behavior

\begin{tabular}{|c|c|c|c|c|c|c|}
\hline \multirow{3}{*}{ Cigarette ads } & \multicolumn{4}{|c|}{ Smoking behaviour } & \multirow{3}{*}{$\mathbf{O R}$} & \multirow{3}{*}{$\mathbf{p}$} \\
\hline & \multicolumn{2}{|c|}{ Not Smoking } & \multicolumn{2}{|c|}{ Smoking } & & \\
\hline & $\mathbf{n}$ & $\%$ & $\mathbf{N}$ & $\%$ & & \\
\hline Not esposed & 11 & 15.5 & 10 & 14.1 & & \\
\hline Exposed & 17 & 23.9 & 33 & 46.5 & 2.14 & 0.148 \\
\hline Total & 28 & 39.4 & 43 & 60.6 & & \\
\hline
\end{tabular}

The results of the calculation of the cigarette ad relationship illustrated the dangers of smoking with smoking behavior in Table 2 shows that the Odds Ratio value of 2.14 means that students exposed to cigarette advertisements are illustrated the dangers of smoking which have a 2.14 times greater likelihood of making students behave smoking than students who are not exposed to cigarette advertisements illustrated the dangers of smoking.
The results of the Chi-Square test show that there is a relationship between cigarette advertisements illustrated the dangers of smoking and smoking behavior and were not statistically significant ( $\mathrm{p}=$ o.148). Table3 showed the OR=0.29 which mean that high self-efficacy of college students waso.29 times more likely to affect students' smoking behavior than students with low self-efficacy. The result of ChiSquare test showed that there was a 
relationship between self-efficacy and smoking behavior and it was statistically significant $(\mathrm{p}=0.020)$.

Multivariate analysis in this study used a multiple logistic regression. The data was processed by using SPSS software. The results of logistic regression showed that there was a relationship between cigarette advertising illustrated the dangers of smoking and smoking behavior after being controlled by the self efficacy variable in Table 4.

The OR score of the cigarette advertising variable illustrated the dangers of smoking was 2.87 , it mean that students who exposed to cigarette advertisements which illustrated the danger of smoking were 2.87 times more likely to smoke than students who were not exposed to cigarette advertisements which illustrated the dangers of smoking. Wald test results showed that there was a relationship between cigarette advertisements which illustrated the dangers of smoking and smoking behavior and it was statistically insignificant $(\mathrm{OR}=2.87 ; 95 \% \mathrm{CI}=0.91$ up to 9.03; $\mathrm{p}=0.071$ ).

Table 4.The relationship between cigarette advertisements which illustrated the dangers of smoking and self-efficacy with smoking behavior

\begin{tabular}{lcccc}
\hline \multirow{2}{*}{ IndependentVariables } & \multirow{2}{*}{ OR } & \multicolumn{2}{c}{ CI 95\% } & \multirow{2}{*}{ p } \\
\cline { 3 - 4 } & & Lower Limit & Upper Limit & \multirow{2}{*}{0.071} \\
The dangers of cigarettes smoking & 2.87 & 0.91 & 9.03 & 0.013 \\
$\begin{array}{l}\text { Selfertising } \\
\text { N observacy }\end{array}$ & 0.23 & 0.07 & 0.74 & \\
-2 log likelion $=71$ & & & & \\
Nagelkerke R $\mathrm{R}^{2}=16.2 \%$ & & & & \\
\hline
\end{tabular}

Odd Ratio of self-efficacy variable was 0.23 , it mean that students with high selfefficacy were 0.23 times more likely to have smoking behavior than students with low self-efficacy. Wald test results indicated that there was a relationship between selfefficacy and smoking behavior which was statistically significant $(\mathrm{OR}=0.23 ; 95 \% \mathrm{CI}=$ 0.07 up to $0.74 ; \mathrm{p}=0.013$ ).

The NegelkerkeR2 score was $16.2 \%$, it mean that dangers of cigarette smoking advertising variables and self-efficacy could explain the smoking behavior by $16.2 \%$ and the remaining $83.8 \%$ was explained by other factors outside the research model.

\section{DISCUSSIONS}

The result of this study showed that there was a relationship between dangers of cigarette smoking advertisingwith result of wald test which showed that there was an insignificant relationship between policy illustrations on cigarette package and smoking behavior $(\mathrm{OR}=2.87 ; 95 \% \mathrm{CI}=0.91$ up to 9.03; $\mathrm{p}=0.071)$. The result of this studysupported a study done by Ariani (2011) which stated that there was a relationship between advertisement and smoking behavior among students.Sunet al., (2011) in their research showed thatstudents felt not significantly disturbed by exposure to cigarette advertisements. The results of a study at the Surakarta Health Polytechnic, as one of the universities in the field of health, so they should have knowledge about the dangers of smoking, those who were highly educated and those who worked in the health sector would avoid smoking behavior.

In reality, students who have knowledge in the health sector also showed that there was insignificant relationship 
between illustration policy on cigarette package and smoking behavior, where they continued to smoke and even enjoyed cigarettes even though warnings about the dangers of smoking have been written clearly in every cigarette package produced, but in reality, smoking behavior did not decrease (Wismanto and Sarwo, 2010).

This supported a statement of Salawati and Amalia (2010), which stated thatFaculty of Health students showed that smoking was good, some claimed to feel the pleasure of smoking after eating, and some claimed to feel the pleasure of smoking while being alone. Another reason was because of the price of the cigarettes. Mubaroket al., (2014) stated thatone of the reasons that the cigarettes were a bestselling commodity in the Indonesian market was the chep price of the cigarettes and they were affordable. In addition, there were no rules related to restrictions on the distribution and consumption of cigarettes in Indonesia so that cigarettes were still a star.

The existence of rules issued by the government did not stop the attractiveness of cigarettes. Cigarette advertisements and promotions in the mass media that were very well packaged were one of the attractions of Indonesian people to smoke. Therefore, the Minister of Health Regulation No. 28 of 2013 was drawn up which would limit the cigarette advertising, promotion and sponsorship, but the implementation of the regulation did not produce clear results to limit and reduce the cigarette consumption.

These results indicated that there was an illustration policy on cigarette package through government regulations stating the dangers of smoking in the hope that people can stop smoking was not an easy matter, because cigarettes contained nicotine which could lead to addictive properties, which could make the smokers be addicted. In addition, the environmental and cultural factors also make the cigarettes to be very hard to stop. Various types of techniques have been carried out to reduce the consumption of cigarettes such as the labeling of cigarette packs, but it would not work to stop the smokers if they did not have intention to stop smoking.

According to Ogden (2007), behavior can be generated through hope, incentives, and social cognition, in these expectations, it included self-efficacy which was the hope that individuals were able to conduct the desired behavior. Therefore, in shaping stop smoking behavior, there must be selfconfidence from the smokers that they were able to stop themselves from smoking. Selfefficacy was found to be associated with the success of stop smoking in adults (T'rietet al., 2008).

Clear evidence of the dangers of smoking has been known to many smokers, but many smokers underestimated the risks that can affect themselves and those around them (WHO, 2011). This smoking behavior has a lot of harm to health, but some people choose to continue smoking. All the smokers must understand that smoking was a bad behavior for themselves and for others. However, most smokers have difficulty in eliminating these habits because they were addicted to the pleasure of cigarettes.

The risk of having a heart attack would be two times greater for heavy smokers, even the risk of facing sudden death due to narrowing of blood vessels was five times greater than people who did not smoke at all. A small amount of nicotine 3 in cigarettes was toxic to the body. Nicotine absorbed in every cigarette smoking was not deadly but still dangerous to the heart. 
Journal of Health Policy and Management (2016), 1(1): 44-52

https://doi.org/thejhpm.2016.01.01.07

The relationship between self-efficacy and smoking behavior

The result of this study showed that there was a relationship between self-efficacy and smoking behavior with the result of wald test which showed thatthere was a relationship between self-efficacy and smoking behavior $(\mathrm{OR}=0.23$; $\mathrm{CI} 95 \%=0.07$ to 0.74 ; $\mathrm{p}=0.013)$. The result of this study supported a study done by Shucket al., (2014) of the 512 research subjects at Netherlands High Schoolwhich found that there was a relationship between self efficacy and adolescents' intention to smoke, this relationship was proven by the intention of adolescents to smoke or not based on their belief in the dangers or benefits of smoking.

Another research about self-efficacy done by Kurniawan (2013) and Mee (2014) showed that self-efficacy affected adolescents' smoking behavior. If adolescents have high self-efficacy, they would refuse to smoke, while adolescents with low selfefficacy would be more interested in smoking.

This was in accordance with the statement of Bandura and Locke (2003) which stated thatadolescent's smoking behavior was also influenced by selfefficacy, namely the individual's belief in his/her ability to perform a particular action well so that the individual tried to show the best that he/she could do to achieve a result or goal maximally. This affected a person to smoke or not. Forming sources of self-efficacy were affected by performance accomplishment), vicarious learning, the influence of social (social persuasion) and emotional arousal (Bandura and Locke, 2003).

The relationship between cigarette smoking advertising and self-efficacy with smoking behavior

The results of this study showed that cigarette advertising which illustrated the dangers of smoking and self-efficacy were able to explain smoking behavior by $16.2 \%$, and $83.8 \%$ was explained by other factors outside the research model..

In this study, the pictures of the dangers of cigarette advertisement was giving visualization of the danger of diseases namely oral cancer, acute throat bronchitis lung cancer, and giving visualization of the danger of cigarette smoke that was very harmful to the children (illustration of the father carrying a child while smoking) and smoking can lead to death (illustration of smoking people beside skull). Warning of the danger of smoking was advertising with images of creepy diseases and hard-tone warning writing that aimed to prevent underage children and novice smokers from consuming and to stop smoking.

Warning of the dangers of smoking did not have a significant effect on the smoking behavior of adolescents, this mean that adolescents did not really care about the image policy, but there was a relationship between self-efficacy and smoking behavior, it showed that a person's smoking behavior was affected by his/her confidence, if adolescents felt confident that cigarettes was not useful, then they would leave it and if the adolescent's self-confidence stated that the cigarette was beneficial to him/her psychologically, then the adolescent would still have smoking behavior.

The conclusion was that there was a positive relationship between cigarette advertisements which illustrated the dangers of smoking and smoking behavior $(\mathrm{OR}=2.87 ; 95 \% \mathrm{CI}=0.91$ to $9.03 ; \mathrm{p}=$ 0.071). There was a negative relationship between self-efficacy and smoking behavior $(\mathrm{OR}=0.23 ; 95 \% \mathrm{CI}=0.07$ to $0.74 ; \mathrm{p}=$ 0.013). Cigarette advertisements which illustrated the dangers of smoking and self- 
efficacy could explain the smoking behavior by $16.2 \%$. $83.8 \%$ was explained by other factors outside the research model.

The suggestions for the Surakarta Health Polytechnic was that the Institution should set and make no smoking regulations in the campus area while also supervising student activities by prohibiting collaboration with the tobacco industry. For students who smoke, they should gradually reduce cigarettes or stop smoking because smoking could damage their health.Student organizations should encourage active participation of students to promote the anti-smoking movement, not only at the Faculty of Health, and actively through campus media to contain information about the dangers of smoking.

\section{REFERENCES}

Ariani RD (2011). Hubungan antara Iklan Rokok dengan Sikap dan Perilaku Merokok pada Remaja (Studi Kasus di SMA Negeri 4 Semarang). Artikel Ilmiah. Semarang: Program Pendidikan Sarjana Kedokteran Fakultas Kedokteran Universitas Diponegoro.

Bandura A, Locke EA (2003). Negative Self Efficacy and Goal Effects Revisited, Journal of Applied Psychology, 88(1): 87-99.

Berry TR, Howe BL (2005). The Effects of Exercise Advertising on Self-Efficacy and Decisional Balance. American Journal of Health Behavior, 2(9): 117126.

BP POM (2005). Upaya Tobacco Control (TC). Info POM. 6(3):2.

Foulds J, Ramstrom L, Burke M, Fagerstrom K (2003). Effect of Smokeless Tobacco (Snus) on Smoking and $\mathrm{Pu}-$ blic Health in Sweden. Tobacco Control, 12(2): 349-359.
Kholish N (2011). Kisah Inspirasi Perjuangan Berhenti Merokok. Yogyakarta: Real Books.

Kumalasari I (2012). Faktor-faktor yang Mempengaruhi Intensi Berhenti Merokok pada Santri Putra di Kabupaten Kudus. Bandung: Program Studi Magister Ilmu Kesehatan Masyarakat Fakultas Kedokteran Universitas Padjadjaran Bandung.

Kurniadi B (2005). Hubungan antara Sikap terhadap Label Peringatan Bahaya Merokok pada Kemasan Rokok dengan Intensi Berhenti Merokok. Naskah Publikasi. Yogyakarta: Fakultas Psikologi Universitas Islam Indonesia Yogyakarta.

Kurniawan T (2013). Pengaruh Paparan Iklan dan Self Efficacy terhadap Perilaku Merokok Remaja. Jurnal Fakultas Ekonomika dan Bisnis, Universitas Kristen Satya WacanaSalatiga, 2(1): 112-120.

Maseda DR, Suba B, Wongkar D (2013). Hubungan Pengetahuan dan Sikap tentang BahayaMerokok dengan Perilaku Merokok pada Remaja Putra di SMA Negeri I Tompasobaru. Ejournal Keperawatan (e-Kp). 1(1): 1-8.

Mee S (2014). Self-Efficacy: A Mediator of Smoking Behavior and Depression Among College Students. Pediatr Nurs. 40(1): 9-15.

Mubarak A, Hamdan, SR, Sumarna EP (2014). Studi Mengenai Faktor Determinan terhadap Intensi Merokok pada Siswa SD N Kota Bandung. Prosiding Seminar Nasional Penelitian dan PKM Sosial, Ekonomi dan Humaniora. Bandung: Fak. Psikologi Universitas Islam Bandung.

Nuradita E, Maryam (2013). Pengaruh Pendidikan Kesehatan terhadap Pengetahuan tentangBahaya Rokok pada Re- 
Journal of Health Policy and Management (2016), 1(1): 44-52

https://doi.org/thejhpm.2016.01.01.07

maja di SMP Negeri 3 Kendal. Jurnal Keperawatan Anak. 1(1): 44-48.

Ogden J (2007). Health Psychology. New York: Open University Press, McGraw Hill.

Salawati T, Amalia R (2010). Perilaku Merokok di Kalangan Mahasiswa Universitas Muhammadiyah Semarang. Prosiding Seminar Nasional Unimus, 172-180.

Sun J, Buys N, Stewart D, Shum D, Farquhar L (2011). Smoking in Australian University Students and Its Association with Socio-Demographic Fac- tors, Stress, Health Status, Coping Strategies, and Attitude. Health Education, 111(2): 117-132.

T'riet JV, Ruiter RAC, Wernij MO, Vries HD (2008). The Influence of Self-Efficacy on The Effects of Framed Health Messages. European Journal of Social Psychology, 38(5):1261-1276.

Wismanto YB, Sarwo YB (2010). Konsistensi Niat dan Perilaku Berhenti Merokok pada Karyawan Sekretariat Daerah Kabupaten/Kotamadya di Jawa Tengah. Indonesian Psychological Journal. 25(2): 1-14. 